\title{
MIOPIA AFETIVA
}

Carolina Alves Magaldi ${ }^{1}$

Sempre acontece na padaria. O café facilita as coisas, talvez pelo calor, ou porque bebê-lo é o máximo de rebeldia que encarno ao contrariar meu gastro.

Hoje foi o rapaz de cabelos quase longos. A blusa uns dois números grande demais, com um buraquinho no punho. Não me pergunte a cor de seus olhos ou o que estava comendo, mas o guardanapo em seu prato parecia um patinho quando o amassou.

Não sei focar o óbvio. Isso por que sofro de miopia afetiva. Demorei a perceber porque ela não cede nem quando vejo de vez em quando uma moça simpática no espelho do banheiro.

Cresci míope e, em um mundo impressionista, os objetos não têm início nem fim, as cores não são absolutas e a luz reina suprema. Tudo que via fazia parte de um todo sem limites, então nunca aprendi a encarar nada isolado.

Quando pus óculos entendi que as coisas eram cada uma uma só, mas o trem das categorias e julgamentos já tinha passado, e eu fiquei sem saber como perceber o que agora via. Os pontos pacíficos de traços, adjetivos e gêneros são sempre bélicos para mim.

\footnotetext{
${ }^{1}$ Doutoranda da Universidade Federal de Juiz de Fora.
} 
Com pessoas é ainda pior, só percebo uma boca depois de uma frase mordaz, os olhos aparecem quando o olhar é doce, e só quando o todo de cada um entra em foco me percebo apaixonada.

Não preciso dizer que não acontece com frequência. Quando o cometa finalmente passa parece não existir mais nada, nem luz nem limites nem cores, a não ser é claro os pães de queijo para acompanhar. 